\title{
A Qurānic Amulet on Papyrus: P.Utah.Ar. 342
}

\author{
W. Matt Malczycki
}

\section{Introduction}

Quranic texts on papyrus are fairly rare: the late Sergio Noja Noseda found only seven published fragments of the Quran on papyrus. ${ }^{1}$ He could have added the P.Bad. v 143 through P.Bad. v 153 and the unpublished P.Duke.inv.274 to this total. ${ }^{2}$ With the possible exceptions of P.Michael. inv. 23 and P.Noseda.Koranic, all of these texts were amulets. P.Utah.Ar. 342 is similar to these other papyri. It contains all of Sūrat al-Ikhlāṣ (Q 112) and Sūrat al-Falaq (Q 113), most of Sūrat al-Nās (Q 114), and the first thirteen verses of Sūrat Yā' Sīn (Q 36). The four süras are parts of prayers and rituals for the sick, dying, and dead. According to hadīth literature, as the prophet Muhammad lay dying he uttered Sūrat al-ikhlāṣ and Sūrat al-falaq (also called al-ma'ūdhātayn). ${ }^{3}$ Also according to hadìth literature, sūra Yā'-Sīn is one of the süras one should recite over the dying and dead. In addition to the Fātiḥa (Q 1) and Sūrat al-Mulk (Q 67), Sūrat Yā' Sīn, Sūrat al-Ikhlāṣ, Sūrat al-Falaq, and Sūrat al-Nās are among the most commonly recited süras in times of sickness, dying, death, and burial. ${ }^{4}$ They are also among those that appear most frequently in Quranic papyrus amulets. ${ }^{5}$

1 Noseda, A third 316.

2 A digital image of P.Duke.inv.274 is available at Duke University's website: http://library.duke .edu/rubenstein/scriptorium/papyrus/records/274.html.

3 For the hadīth that al-Bukhārī relates in reference to the last three sūras of the Quran, see al-'Asqalānī, Fath al-bārī 74-79. In other editions of al-Bukhāri's Şậ̄h, one can find these hadìths in the chapters about the moral excellence of the Quran (fadāill al-qurān).

4 Abū Dāwūd and Ibn Mājah relate hadīths that say that Sūrat Yā' Sīn was appropriate for prayers for the dying and in funerals. In most editions of hadith collections, one can find these hadìths under the chapters relating to funerals (al-janāiz) (Abū Dāwūd, Sunan Abì Dāwūd vol. 5pt. 2, 543; Ibn Mājah, Sunan Ibn Mājah, 7:212). Al-Tirmidhī describes Sūrat Yä'-Sīn as "the heart of the Qurān" (al-Mubārakfūrī, Tuhfat 196-198). This passage is in the chapter entitled "Faḍāil al-qurān" in most editions of al-Tirmidhī's Jāmi'. These are only a few of the references to the süras in question that one can find in the hadith literature.

5 P.Bad. V 147 contains the first lines of Sūrat Yä' Sīn. P.Bad. v 145, 151, and 153 contain part or all of Sūrat al-Ikhlāṣ. P. Bad. v 143 contains each of the last three sūras. P.Duke.inv.274 contains Sūrat al-Falaq and Sūrat al-Nās.

(C) W. MATT MALCZYCKI, 2015 | DOI:10.1163/9789004284340_013

This is an open access chapter distributed under the terms of the prevailing CC-BY-NC License at the time of publication. 


\section{P.Utah.Ar. $342(21.2 \times 32.5 \mathrm{~cm})$}

This is a good quality brown papyrus with a small papyrus cord in the upper middle part of the papyrus. The verso has traces of writing, but it seems that these were washed out. ${ }^{6}$ On the verso the four vertical folding marks are also clearly visible. There is one fold in the centre, another fold mark $2.12 \mathrm{~cm}$ to the right of centre, another fold mark $2.9 \mathrm{~cm}$ to the left of centre, another fold mark $5.9 \mathrm{~cm}$ left of centre, and another fold mark $9.8 \mathrm{~cm}$ left of centre.

The recto contains separate texts on the right and left sides of the centre fold. The margin between the right and left sides of the text ranges from 2.5 to $3.5 \mathrm{~cm}$. The text runs parallel to the fibres. The ink is black and the strokes are thicker than normal for a papyrus-era text. The right side of the recto contains all of Sūrat al-Ikhlāṣ and Sūrat al-Falaq. It also contains Sūrat al-Nās albeit with some omissions - the scribe omits the second verse (malik al-nās), the third verse (ilāh al-nās), and the word al-nās from the fifth verse. There is an intermittent vertical lacuna on the right side that ranges between 0.3 and $1 \mathrm{~cm}$ wide and runs through the text beginning between 4 and $4.5 \mathrm{~cm}$ from the right margin.

The left side of the recto contains most of the first thirteen verses of Surrat Yầ Sīn. The left side text contains many more lacunae than the right side, including a large one $(6 \times 6.5 \mathrm{~cm})$ in the centre that would have contained most of lines 7-11. Lines 11-12 are badly damaged, but enough text remains to offer a reconstruction. Lines 13-16 are all but obliterated, so the edition that follows is based on the amount of text that the scribe could most probably have fit on the remainder of the page. It seems that the scribe made an effort to imitate an angular script in the first few lines, but overall the script is more curved than angular. There are no consonantal diacritical marks, and there are also no symbols to separate the verses.

In the Arabic edition that follows, I have attempted to be as faithful to the original papyrus text as possible. To that end, I have not added consonantal diacritical marks, tanwin, hamza, or any other letters or pronunciation signs except when filling in lacunae and adding scribal omissions. I have added the missing verses and words in angular brackets, but I have not corrected the scribe's use of the plural where, according to the canonical edition of the Quran, he should have used the singular. The word Allāh is spelled with shadda and alif qașira.

6 Lola Atiya's inventory says that the recto is blank and that text is on the verso. She also says that two scribes were at work. A closer analysis reveals that this was not the case (Atiya, University $32)$. 
The English translation that follows is an adaptation of the pertinent passages of Arberry's The Koran Interpreted. ${ }^{7}$ The chapter and verse numbers from the canonical version of the Quran appear in double parentheses. In cases in which the scribe broke words between two lines, the English equivalents are also broken in the translation. One is forced to admit that the bracketing of the portions of English words is arbitrary, but there seems to be no other way to be true to the text. The rest of the punctuation marks are standard papyrological symbols.

\section{Translation: Right Side}

$1 \quad((\mathrm{Q} 112))$ In the Name of God, the Merciful, the Compassionate

2 ((1)) Say: 'He is God, One, ((2)) God the Everlasting Refuge, ((3)) who has not

3 [be]gotten, and has not been begotten $((4))$ and equal to him is not

4 anyone.'

5 ((Q 113)) In the Name of God, the Merciful, the Compassionate

6 ((1)) S[ay:] 'I take refuge with the Lo[rd] of the [Day]break ((2)) from the evil of what He has created,

7 ((3)) from the evil of darkness when it gathers,

$8 \quad((4))$ and from the evil of women who blow on knots

$9 \quad((5))$ and from] the ev[il] of an envier when he envies.'

10 ((Q 114)) In the name of God, the Merciful, the Compassionate

11 ((1)) Say: 'I take refuge with the Lord of men $\langle((2))$ the King of men, $((3))$ the God of men, $\rangle((4))$ from the evil of the whisperer,

12 the withdrawer, ${ }^{8}((5))$ who whispers in the brea-

13 sts $\langle$ of men $\rangle$ of jinn and me-

$14-n$

15 ((Q 36)) In the name of God, the Merciful, the Compassionate

7 Arberry, The Koran $353^{-} 354$.

8 Here I have diverged from Arberry and translated al-Khanās as "the withdrawer." Al-Khanās refers, of course, to the Devil, who withdraws at the mention of God. 


\section{Translation: Left Side}

$1 \quad((1))$ Yầ $\operatorname{Sin}((2))$ By the Wise Quran ((3)) thou art truly among the Envoys

$2 \quad((4))$ on] a straight path $((5))$ the sending down of the All-mighty,

3 the All-]wise $((6))$ that thou mayest warn a people whose fathers

4 [were] never warned, so they are heedless. $((7))$ The Word has been realised against

$5 \quad$ [most] of them, yet they do not believe. ((8)) Surely We have put

6 [on] their necks fetters up to the chin,

$7 \quad$ [so their] heads are rais[ed; $((9))$ and We have put] before them

8 [a bar] rier and [behind them a barrier; ] and We have covered them up,

9 so they [do not see. ((10)) Alike it is] to them

10 [whether thou hast warned] them [or thou hast not warned them, they do not bel]ieve. $[((11))$ Thou only

11 warnest him who [follows the Remembrance and] who fears the A[ll]merciful

12 [in the Unseen; ] so give them ${ }^{9}$ good tidings of forgive[ness and a gener-

13 ous wage. ((12)) Surely it is We who [bring the dead to life

14 [and write down what they have forwarded and what they have left behind; Every-]

15 [thing We have numbered in a clear register.]

$16 \quad[((13))$ Strike for them a similitude - the inhabitants of the city ...]

\section{The Text: Right Side}

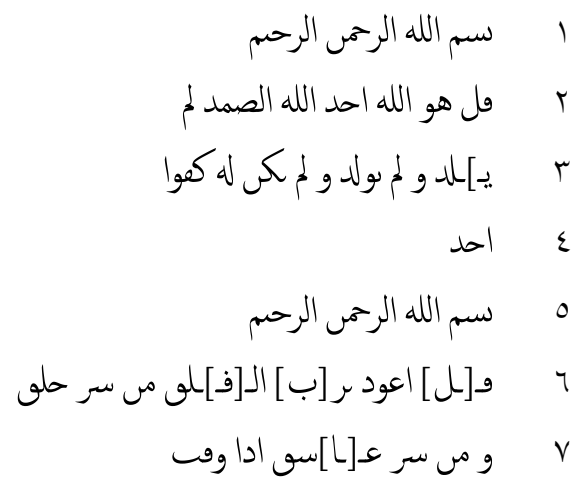

9 Arberry's translation reads "him" instead of "them." Arberry, The Koran 144. However, as will be explained below, the papyrus uses the plural rather than the singular. 


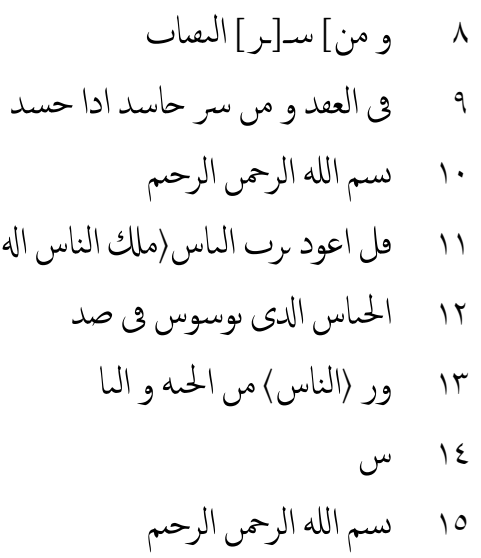

The Text: Left Side

$$
\begin{aligned}
& \text { ا س و العران الحكم اكى لم المرسلس } \\
& \text { r [على] صراط مسعم سربل العربر }
\end{aligned}
$$

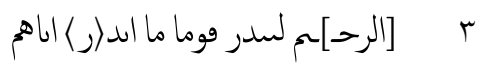

$$
\begin{aligned}
& \text { ع [ف][هم عافلون لعد حى العول على }
\end{aligned}
$$

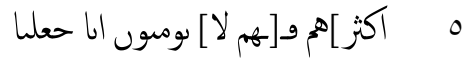

$$
\begin{aligned}
& \text { 7 }
\end{aligned}
$$

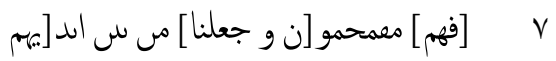

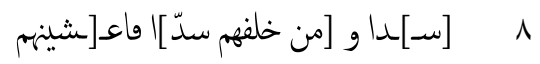

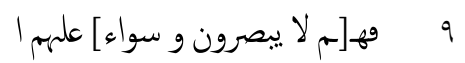

$$
\begin{aligned}
& \text {. } 1 \text { [نذرت] } \\
& \text { | } 11 \\
& \text { Ir ] [بالغيب] فسرهم مععر [ةو اجر كر] }
\end{aligned}
$$

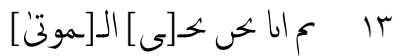

$$
\begin{aligned}
& \text { ع ا [و نكتب ما قدموا اوءاثر هز وكل] } \\
& 10 \\
& 17 \text { [و اضظرب لمم مثلاً اصحنب القرية اذ] }
\end{aligned}
$$




\section{Notes: Right Side}

1. The scribe attempted to imitate the Kufic script, and there are some paleographic features of the script that are more typical of early texts than later ones. ${ }^{10}$ There are, for example, incomplete final upward strokes of the nūn (right side lines 1, 3, 5, 6, 7, 10, and 13; left side lines 1, 4, 5, and 11), horizontally elongated oblique strokes of the $k \bar{a} f$ and șād (right side lines 2 and 3), and hooked dāls (right side lines 2 and 3 ).

The horizontal extension of the letter $h \bar{a}$ in al-rahmmann (the Merciful) is an example of mash $q$, the technique in which scribes lengthen words horizontally to fill lines for aesthetic effect. ${ }^{11}$

The downward horizontal curved nün that is extended without being completely returned to the horizontal axis of the line is typical of Arabic handwriting from the first through the third Islamic centuries. ${ }^{12}$

2. The horizontal extension of the oblique stroke of the final $d \bar{a} l$ and the small upward right hook of this stroke in the words ahad (one) and al-șamad (the everlasting refuge) are typical of second/eighth-century scripts. ${ }^{13}$ The horizontal extension of the letter șād in the word al-șamad also is common in the Kufic scripts of all eras. The angularity of the script in these first two lines gives the impression that the scribe was trying to execute and perform the Kufic script in the first few lines.

3. The horizontal extension of the oblique stroke of the letter $k \bar{a} f$ and the upward right hook of this stroke in the words yakun and kufuwan is typical of second/eighth-century penmanship. ${ }^{14}$ The scribe uses alif to indicate the

10 The script of P.Utah. Ar. 342 resembles what François Déroche describes as "the New Style" in his The Abbasid Tradition: Qurans of the 8th to 1oth Centuries. Here Déroche argues that the traditional categories of $k \bar{u} f \iota$ and naskhi are not totally accurate, and, accordingly, he introduces a new category, "the New Style." The New Style is more round than küfi scripts but not as round as naskhi scripts. Déroche says that the New Style first appears in non-Quranic texts datable to the third/ninth century and in Quranic manuscripts datable to the fourth/early tenth century (Déroche, The Abbasid 132-137).

11 For mashq, see Abbott, The rise 23-28. Al-Sijistāni relates that as early as four generations before his time, some scholars disliked the use of mashq in Quranic texts (al-Sijistānī, Kitāb al-mașāhif 134).

12 Gruendler, The development 100-104.

13 P.Khalili I, 29-32.

14 Gruendler, The development 88-92; P.Khalili I, 34-37. 
accusative case of the word, kufuwan, although there are no marks to indicate tanwin. The alif in this word bends down to the right at the bottom, a tendency typical of early scripts..$^{15}$

4. From this line forward, the script becomes more curved as the scribe abandoned his attempt to imitate Kufic. Although some of the $d \bar{a} l s / d h a \bar{l} l s$ have the upward hook typical of early papyri, all of them after line 4 in the right side lack this feature. ${ }^{16}$ All of the scribal tendencies from this point forward suggest a third/ninth-century date of composition.

8. In the word al-naffāthāt, the scribe of P.Utah. Ar. 342 writes mater lectionis alif after the $f \bar{a}^{\prime}$ but not after the thä'. According to al-Dānī, the word al-naffāthāt should be spelled without alif, although in modern editions of the Quran, one finds a lif qașira in place of mater lectionis alif. ${ }^{17}$

9. The rightward bend of the $y \bar{a}^{\prime}$ in $f \grave{\imath}$ is typical of all papyrus-era texts..$^{18}$

11. In the canonical versions of the Quran, there are two more verses than there are here. These verses come between the words bi-rabb al-nās and al-waswās. These two verses are short (two words each), and both end with the word al-nās..$^{19}$ Such omissions are common in Quranic papyri.

\section{Notes: Left Side}

1. Size is the main difference between the scripts of the right and left sides. In the left side of the text, the scribe writes his letters smaller, avoids mashq entirely, and decreases the space between lines. This reduced size of the letters is most apparent in the final forms of $\sin , n \bar{u} n$, and $y \bar{a}$. None of the letters with the exception of the $k \bar{a} f$ in line 1 exhibit features common in early papyri.

\footnotetext{
15 Abbott, The rise plate v; P.Khalili I, 27-29.

16 P.Khalili I, 29-32.

17 al-Dānī, Kitāb al-Muqni` 24 .

18 Gruendler, The development 112-116; P.Khalili I, 38-42.

19 Ibn Wathīq al-Andalusī (d. 462/1070) mentions that some people added words to this sūra and thereby lengthened it, but he does not say that there are any instances of its having been shortened $(1988,150)$.
} 
2. The scribe spells șirāt mustaqìm with mater lectionis alif. According to al-Dānī (d. 462/1070), the 'ulama $\bar{a}$ ' of all regions agreed that it should be written without it. $^{20}$

4. In the last word of the line, 'alä, one sees the omission of the alifmaqșüra that is typical of Arabic papyri. ${ }^{21}$

6. The orthography of the word aghläl here is interesting. Al-Dānī says that scribes spelled aghlälan with alif qașira (or no alif at all) in place of the mater lectionis alif between the läms, and with tanwin fatha seated on a prosthetic alif marking the accusative case at the end of the word. Here the scribe uses the mater lectionis alif between the first and second läms and omits the alif of tanwin fatha. Al-Dānī does not record this spelling of aghlāl. ${ }^{22}$

12. The phrase fa-bashshirhum merits comment because it ends with the third person plural enclitic pronoun -hum whereas the now-standard version of the Quran contains the singular - $h u$. If line 11 were intact, one could examine it to find out if the scribe treated the verb ittab'a the same way.

This is not a variant known from the different lists of qiräät. Rather, scribal error explains the scribe's use of -hum instead of -hu as well as the missing $\bar{a} y a$. Verse 11 of Sūrat Yā' Sīn reads innamā tundhiru man-ittab'a al-dhikra wa khashiya al-rahmmāna bi-l-ghaybifa-bashshirhu bi-maghfiratin wa-'ajrin karimin. The conjunctive particle man is singular and indeclinable; however, it can convey a collective meaning (i.e. those, those who). ${ }^{23}$ Perhaps the scribe assumed that he was to take man to mean "those who" rather than he who and then added -hum to fa-bashshir- accordingly. ${ }^{24}$ That a constructio ad sensum lies behind this variant is an attractive thought as it appears in many other Quranic

$20 \quad$ al-Dānī, Kitāb al-Muqnic 97.

21 Hopkins, Studies 57-6o.

22 al-Dānī, Kitāb al-Muqni' 19.

23 For a treatment of man, see Wright, Grammar 2:273.

24 Another explanation for the use of -hum is that the scribe made a careless mistake because of the context in which verse 10 appears. Throughout this part of Sürat Yā'-Sīn, God is speaking to the Prophet about other groups of people: those who have heard no revelation (verse 6), those who refuse to listen to revelation (verse 7), those whom God has shut off from the light of revelation and punished (verses 8-10), and the dead (verse 13). The first person subject is always plural. The second person subject is always singular. With the exception of verse 10 all third-person subjects and objects are plural. Therefore, the third person singular that one finds in verse 10 is, in a sense, out of place. 
papyrus fragments. Regardless of how one explains it, the use of the plural pronoun here does not change the meaning of the verse. It is a minor variation that is most likely due to scribal error.

\section{Bibliography}

\section{Primary Sources}

Abū Dāwūd (d. 275/889), Sunan Abī Dāwūd. Jāmic jawāmic al-ahādīth wa al-asānīd wa maknaz al-șihăh̆ wa al-sunan wa al-masānīd, Cairo 2001.

. Kitāb al-Mașāhif, ed. A. Jeffery, Leiden 1927.

al-Andalusī (d. 462/1070), Al-Jāmi fì mã yuhtāju ilayhi min rasm al-mașhaf, ed. Gh.Q. Ḥamad, Baghdad 1988.

al-Dānī (d. 462/1070), Kitāb al-Muqni' fì rasm masāhịf al-amsāar ma'a kitāb al-naqț, ed. O. Prezl, Istanbul 1932.

Ibn Ḥajar al-'Asqalānī (d. 852/1448), Fatḥ al-bārū sharh șaḥịh al-Bukhārī, vol. 9, ed. 'A al-A. ibn Bāz, Riyadh 2000.

Ibn Mājah (d. 273/887), Sunan Ibn Mājah. Jāmic jawāmic al-ahādīth wa al-asānìd wa maknaz al-sihịḥh wa al-sunan wa al-masānīd, ed. Jamīat al-Maknaz al-Islāmī, Cairo 2001.

al-Mubārakfūrī (d. 1353/1934), Tuhfat al-aḥwadhī bi-sharh jām‘i al-Tirmidhī, ed. 'A. al-R. 'Uthmān, Medina 1968.

Ibn Mujāhid (d. 324/936), Kitāb al-saba'a fì al-qirä̀āt, ed. Shawqī Ḍayf, Cairo 1972.

Ibn al-Nadīm (d. 385 /995), Al-Fihrist, ed. Y.'A. Tawīl, Beirut 1996.

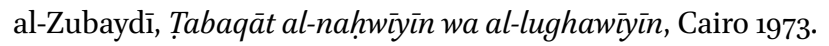

\section{Secondary Sources}

Abbott, N., The rise of the north Arabic script and its Kur'ānic development, with a full description of the Kur'ān manuscripts in the Oriental institute, Chicago 1939.

Alain, G., The geometry of early Qur'ānic manuscripts, in Journal of Quranic Studies 9 (2007), 78-110.

'Alī, 'A.A.Y., The meaning of the holy Qur'ān, Beltsville, Maryland 1989.

Anawati, G.C., Trois talismans musulmans en arabe provenant du Mali (marché de Mopti), in Annales Islamologiques 11 (1972), 287-339.

Arberry, A.J., The Koran interpreted, 2 vols. in one book, New York 1996.

Arkoun, M., Introduction: An assessment of and perspectives on the study of the Qur'ān, in A. Rippin (ed.), The Quran: Style and contents (The formation of the classical Islamic world 24), Burlington, VT 1982, 297-332, repr. 2001.

Atiya, L., University of Utah Arabic collection. Marriot Library, University of Utah (photocopy), n.d. 
Baalbaki, R., The treatment of qirāāt by the second and third century grammarians, in A. Rippin (ed.), The Qur'ān: Formative interpretation (The formation of the classical Islamic world 25), Burlington, VT 1985, 159-180, repr. 1999.

Blair, S., Islamic calligraphy, Cairo 2006.

Böwering, G., Recent research on the construction of the Qurān, in G.S. Reynolds (ed.), The Qur'ān in its historical context, New York 2008, 70-87.

Canaan, T., The decipherment of Arabic talismans, in E. Savage-Smith (ed.), Magic and divination in early Islam (The formation of the classical Islamic world 42), Burlington, VT 1937, 125-178, repr. 2004.

Déroche, F., Catalogue des manuscrits arabes, deuxième partie Manuscrits Musulmans, tome I, 1: Les manuscrits du Coran aux origines de la calligraphie coranique, Paris 1983.

. The Abbasid tradition: Qurans of the 8th to 1oth centuries, Oxford 1992.

- Manuel de codicologie des manuscrits en écriture arabe, Paris 2000.

- New evidence about Umayyad book hands, in Essays in honor of Șalāḥ al-Dīn al-Munajjid, London 2002, 611-642.

- Written transmission, in A. Rippin (ed.), The Blackwell companion to the Qur'ān, Oxford 2006, 172-186.

Diem, W., Untersuchungen zur frühen Geschichte der arabischen Orthographie I: Die Schreibung und Vokale, in Orientalia 48 (1979), 247-258.

- Untersuchungen zur frühen Geschichte der arabischen Orthographie II: Die Schreibung der Konsonanten, in Orientalia 49 (1980), 67-106.

- Untersuchungen zur frühen Geschichte der arabischen Orthographie III: Endungen und Endschreibungen, in Orientalia $5^{\circ}$ (1981), 176-192.

Dols, M.W., The theory of magic in healing, in E. Savage-Smith (ed.), Magic and divination in early Islam (The formation of the classical Islamic world 42), Burlington, VT 1992, 87-102, repr. 2004.

Fedeli, A., Early evidences of variant readings in Qurānic manuscripts, in K.-H. Ohlig and G.-R. Puin (eds.), Die dunklen Anfänge: Neue Forschungen zur Entstehung und frühen Geschichte des Islam, Berlin 2005, 293-316.

Grob, E., Documentary Arabic private and business letters on papyrus: Form and function, content and context, New York 2010.

Grohmann, A., The problem of dating early Qurans, in Der Islam 33 (1958), 216-231.

—. Die Entstehung des Koran und die ältesten Koran-Handschriften, in Bustan: Österreichische Zeitschrift für Kultur, Politik, und Wirtschaft der Islamischen Länder 2 $(1961), 33-38$.

Gruendler, B., The development of the Arabic scripts from the Nabatean era to the first Islamic century, Atlanta 1994.

Hamdan, O., The second mașāhif project: Step towards the canonization of the Qur'anic text, in A. Neuwirth, N. Sinai and M. Marx (eds.), The Qur'an in context: Historical and literary investigation into the Quranic milieu, Leiden 2010, 795-835. 
Hamès, C., La notion de magie dans le Coran, in C. Hamès (ed.), Coran et talismans. Textes er pratiques magiques en milieu musulman, Paris 2007, 17-49.

Hopkins, S., Studies in the grammar of early Arabic, Oxford 1984.

Hoyland, R., Epigraphy and the linguistic background of the Qurān, in G.S. Reynolds (ed.), The Qur'ān in its historical context, New York 2008, 51-69.

al-Imam, A.'A., Variant readings of the Qur'an: A critical study of their historical and linguistic origins, Washington and London 2006.

Ibn Warraq, Some additions to A. Jeffery and I. Mendelsohn, and some pages from the Samarqand Qur'ān codex, in Ibn Warraq (ed.), Which Koran? Variants, manuscripts, linguistics, Amherst, New York 2011.

Jeffery, A., Materials for the history of the text of the Quran, Leiden 1937-1951.

and I. Mendelsohn, The orthography of Samarqand Qur'an codex, in Journal of the American Oriental Society 62 (1942), 182-195.

Kaplony, A., What are those few dots for? Thought on the orthography of the Qurra papyri, the Khurasan documents, and the inscription of the Jerusalem Dome of the Rock, in Arabica 55 (2008), 91-112.

Khan, G., Standardisation and variation in the orthography of the Hebrew bible and Arabic Qurān manuscripts, in Manuscripts of the Middle East 5 (1990-1991), 5358.

Leemhuis, F., From palm leaves to the internet, in J. Dammen McAuliffe (ed.), The Cambridge companion to the Qur'ān, Cambridge 2006, 145-162.

Loebenstein, H., Koranfragment auf Pergament aus der Papyrussamlung der Österreichische Nationalbibliothek, Vienna 1982.

Loth, O., Zwei arabische Papyrus, in Zeitschrift der Deutschen Morgenländischen Gesellschaft 34 (1880), 685-691.

Manzoor, S.P., Method against truth: Orientalism and Qur'ānic studies, in A. Rippin (ed.), The Quran: Style and contents (The formation of the classical Islamic world 24), Burlington, VT 1987, 399-416, repr. 2001.

Noseda, S.N., A third Koranic fragment on papyrus: An opportunity for revision, in Rendiconti 137 (2003), 313-326.

Padwick, C.E., Muslim devotionals: A study of prayer manuals in common use, Rockport, MA 1961, repr. 1997.

Puin, G.-R., Observations on early Qur’ānic manuscripts in Șanā', in S. Wild (ed.), The Qur'ān as text, Leiden 1996, 107-112.

Rāgib, Y., Les plus anciens papyrus arabes, in Annales Islamologiques 30 (1996), 1-19.

Reynolds, G.S. (ed.), The Qur'ān in its historical context, New York 2008.

Reynolds, L.D. and N.G. Wilson, Scribes and scholars: A guide to the transmission of Greek and Latin literature, 3rd ed., Oxford 1991.

Rezvan, E.A., The Qur'ān and its world vir. Talisman, shield, and sword, in Manuscripta Orientalia 4 (1998), 24-34. 
The Qurān and its world v. Language, the unconscious, and the 'real world,' in Manuscripta Orientalia 4 (1998), 26-39.

Robin, C.J., La réforme de l'écriture arabe á l'epoque du califat médinois, in Mélanges de l'Université Saint-Joseph 59 (2006), 319-364.

Sadheghi, B. and U. Bergman, The codex of a companion of the prophet and the Qur'ān of the prophet, in Arabica 57 (2010), 343-436.

and M. Goudarzi, Șan'ā' 1 and the origins of the Qur’ān, in Der Islam 87 (2012), 1-129.

Schoeler, G., The oral and the written in early Islam, ed. J.E. Montgomery, trans. U. Vagelpohl, New York 2006.

The codification of the Qur'an: A comment on the hypotheses of Burton and Wansbrough, in A. Neuwirth, N. Sinai and M. Marx (eds.), The Qur'an in context: Historical and literary investigation into the Quranic milieu, Leiden 2010, 779-794.

Versteegh, C.H., The Arabic language, New York 1997.

Watt, W.M., Bell's introduction to the Quran, Edinburgh 1970.

Whelan, E., Forgotten witness: Evidence for the early codification of the Quraan, in Journal of the American Oriental Society 118 (1998), 1-14.

Wouters. A., From papyrus scroll to papyrus codex: Some technical aspects of ancient book fabrication, in Manuscripts of the Middle East 5 (1990-1991), 9-19.

Wright, W., Grammar of the Arabic language. Revised and edited by W. Robertson Smith and M.J. de Goeje, 2 vols, 1859, repr. 2 vols. in 1, Cambridge 1999. 